See discussions, stats, and author profiles for this publication at: https://www.researchgate.net/publication/328600300

\title{
SIMPOSIUM NASIONAL KOMUNIKASI KESEHATAN 2015 (BOOK CHAPTER : FENOMENA PENGOBATAN MINYAK BINTANG EFEK MINIMNYA KEPERCAYAAN PASIEN TERHADAP PENGOBATAN BIOMEDIS)
}

Book · September 2015

1 author:

Mochammad Wahyu Ghani

Indonesian Institute of Sciences

5 PUBLICATIONS OCITATIONS

SEE PROFILE

Some of the authors of this publication are also working on these related projects:

Penelitian Prioritas Nasional 2019: Kondisi Sosial Demografi, Layanan Pendidikan, dan Kesehatan bagi OAP View project 


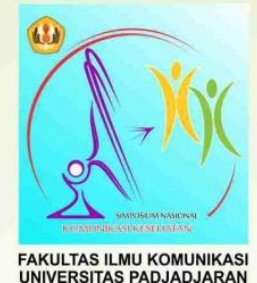

\section{SIMPOSIUM NASIONAL KOMUNIKASI KESEHATAN 2015}

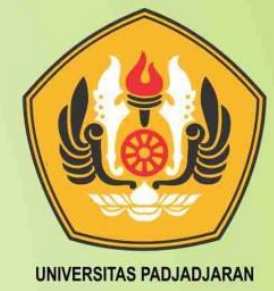

\section{"KOMUNIKASI KESEHATAN DI INDONESIA : PROSPEK, TANTANGAN DAN HAMBATAN"}

\section{PROSIDING}

Diterbitkan oleh: Lembaga Penelitian, Pengabdian Kepada Masyarakat, dan Penerbitan (LP3),

Fakultas IImu Komunikasi Universitas Padjadjaran

\section{Bale Sawala \& Kampus Fikom} 16 September 2015 


\title{
FENOMENA PENGOBATAN MINYAK BINTANG EFEK MINIMNYA KEPERCAYAAN PASIEN TERHADAP PENGOBATAN BIOMEDIS
}

\author{
Mochammad Wahyu Ghani ${ }^{146}$
}

\begin{abstract}
ABSTRAK
Minyak bintang merupakan sarana pengobatan personalistik diluar rasionalitas yang dapat menyambuhkan suatu penyakit terutama patah tulang dengan sekejap. Apabila dihubungkan dengan ilmu medis kedokteran, hal ini adalah sebuah fenomena yang mustahil terjadi. Tetapi hal ini benar-benar terjadi di daerah Kalimantan terutama kota Samarinda. Konon proses pembuatan minyak ini tidak sembarang orang yang mampu membuatnya, minyak ini dibuat dari suatu ramuan tertentu dengan dicampur kekuataan gaib. Dalam penulisan makalah ini, fenomena minyak bintang akan diulas dari salah satu komponen komunikasi, yaitu pesan. Dalam aktifitas komunikasi terapeutik, pesan adalah sesuatu yang sangat penting. Tanpa pesan, seorang komunikator tidak akan sanggup menjadi seorang komunikator karena tidak ada yang disampaikan. Dalam konteks budaya di Indonesia tentunya komunikator yang mampu mengolah pesan high context akan lebih berhasil mempengaruhi pasien daripada pesan low context yang biasanya dipraktekan oleh petugas medis. Karena itu pengobatan minyak bintang tetap dipercaya oleh sebagian masyarakat Samarinda sebagai pengobatan alternative karena pembawaan pesan yang disampaikan lebih bersifat implisit.
\end{abstract}

Kata Kunci: Pengobatan Personalistik, Minyak Bintang, high context, low context

\section{ABSTRACT}

"Minyak Bintang" is a treatment personalistic beyond rationality that can cure a disease mainly fractures with a snap. If connected to the medical science of medicine, it is a phenomenon that is impossible. But this is actually happening in Kalimantan especially in Samarinda city. It is said that the process of making this oil is not just anyone who is able to make it, this oil is made from a specific concoction with mixed power of the occult. In this research, the phenomenon of "Minyak Bintang" will be reviewed from one component of communication, that is messages. In the activity of therapeutic communication, the message is something which very important. Without a message, a communicator will not be able to be a communicator because nothing is delivered. In the context of the culture in Indonesia is certainly communicator which is able to process high message context will be more successful in influencing patients than low message context which usually practiced by medical personnel. Because of that treatment of " minyak Bintang” still believed by some people in Samarinda as a treatment alternative for conveying the message are be submitted is more implicit

Keywords: Treatment personalistic, “minyak bintang”, high context, low context

\footnotetext{
${ }^{146}$ Universitas Padjadjaran, wayghani@gmail.com
} 


\section{PENDAHULUAN}

Sistem pengobatan modern telah berkembang pesat di masa sekarang ini dan telah menyentuh hampir semua lapisan masyarakat. Dalam kenyataannya, pada saat ini perkembangan praktik-praktik pengobatan medis modern selalu diiringi dengan perkembangan praktik-praktik pengobatan tradisional. Hal tersebut ditunjukkan dengan adanya pengobatan tradisional yang masih tetap hidup dan menjadi model pengobatan alternatif dalam masyarakat. Kondisi yang demikian menunjukkan bahwa health care merupakan salah satu fenomena sosial budaya yang kompleks yang melibatkan banyak faktor didalam kehidupan masyarakat secara umum dan khusus

Karena itu tidak heran apabila saya menemukan sebuah fenomena diluar rasionaliatas yang terjadi di kota samarinda. Di Ibukota provinsi Kalimantan Timur tersebut terdapat sebuah fenomena unik tentang terapi penyembuhan menggunakan minyak bintang. Minyak bintang adalah sejenis obat alternatif yang berbentuk minyak, yang bisa dioleskan ataupun digosok ke bagian yang sakit. Tetapi lebih sering minyak bintang ditelan secara langsung sebagaimana kita menelan sesuatu. Lalu apa bedanya dengan obat alternative yang lain?, Minyak bintang memiliki kekuatan penyembuhan yang sangat cepat dan sangat diluar rasionalitas. Minyak bintang mampu menyembuhan penyakit patah tulang hingga remuk tulang hanya dalam jangka waktu paling lama seminggu, bahkan bisa semalam apabila mengikuti syarat-syarat tertentu.

Minyak ini sering disebut minyak sakti, minyak yang langka. Hal ini dikarenakan Sangat sulit mencari pembuat asli minyak bintang saat ini. Selain itu, dalam proses pembuatan minyak ini tidak sembarang orang yang mampu membuatnya, selain dari segi bahan-bahannya yang rumit dan pembuatnya harus memiliki silsilah keturunan yang berasal dari keturunan si pembuat minyak bintang, minyak ini dibuat dari suatu ramuan tertentu dengan dicampur (konon) kekuataan gaib.

Dikatakan minyak bintang karena didalam proses pengisian kekuatannya selain bahan-bahan yang diatas juga menggunakan kekuatan sinar bintang, minyak yang sudah disiapakan, ditaruh dibawah sinar bintang dengan dibacakan mantera-mantera ataupun doa khusus. Umumnya berdasarkan cerita para tetua minyak bintang dibuat pada hari jumat saat bintang sangat bersinar terang.

Minyak bintang begitu tersohor di bumi kalimantan, sehingga banyak sekali orang yang mencarinya. Minyak bintang tentu saja juga memiliki efek samping bagi si pemakai 
minyak bintang. Efek sampingnya antara lain akan merasakan kesakitan setelah memakainya dalam satu malam, terutama bagian yang diolesi dengan minyak bintang. Maka pada bagianbagian itu akan terasa seperti disayat-sayat atau di tusuk-tusuk. Terkadang ada juga pengguna minyak bintang yang mengatakan sakitnya seperti kulit tubuh terasa dikuliti.

Menurut pandangan masyarakat setempat, pada saat inilah para jin-jin yang berada didalam minyak bintang mulai bereaksi dan bekerja baik untuk kekebalan tubuh, menyembuhkan penyakit, mengembalikan tulang yang patah, luka, dan sebagainya. Apabila dihubungkan dengan ilmu medis kedokteran, hal ini adalah sebuah fenomena yang mustahil terjadi. Tetapi hal ini benar-benar terjadi di daerah Kalimantan atau samarinda pada khususnya. Konon minyak bintang adalah obat yang terbuat dari bahan baku yang tidak sembarangan didapat.

Fenomena minyak bintang tidak bisa lepas dari dari salah satu komponen komunikasi, yaitu pesan. Dalam aktifitas komunikasi, pesan juga adalah sesuatu yang sangat penting. Tanpa pesan, seorang komunikator tidak akan sanggup menjadi seorang komunikator karena tidak ada yang disampaikan. Pesan adalah sesuatu yang disampaikan oleh komunikator, maka dari itu pesan yang baik harus direncanakan sebaik mungkin dan juga bagaimana pesan tersebut nanti disajikan agar komunikan sanggup menerima pesan yang kita maksud dalam hal ini pasien yang berobat menggunakan minyak bintang. Penyembuh/ healer memiliki kemampuan menyampaikan pesan yang sangat baik kepada pasiennya, hal ini dikarenakan mereka menggunkan pola komunikasi konteks tinggi sehingga dapat diterima masyarakat setempat. Menurut Jalaludin Rakhmat Di dalam buku psikologi komunikasi (2011, 290), Penysunan dan penyajian pesan yang baik juga sangat memperkuat efek pesan persusasif. Organisasi pesan, struktur pesan dan imbauan yang baik akan membantu penyembuh dalam menyampaikan pesan tentang minyak bintang bintang.

Peran petugas kesehatan yang tidak maksimal dalam menjalin komunikasi antar budaya yang baik dan efektif juga ikut "membantu" mensuburkan pengobatan alternative ini. Dalam komunikasi antar budaya, komunikasi antarbudaya adalah komunikasi antara orangorang yang berbeda kebudayaan, misalnya antar suku bangsa, etnis, ras dan kelas sosial (Samovar \& Porter 2010, 8). Samovar dan Porter juga menjelaskan bahwa komunikasi antarbudaya terjadi diantara produsen pesan dan penerima pesan yang latar belakang kebudayaannya berbeda. Hal inilah yang terkadang tidak disadari oleh petugas kesehatan yang biasanya menggunakan pola komunikasi konteks rendah terhadap pasiennya dibandingkan pengobatan alternative yang biasanya menggunakan komunikasi konteks tinggi terhadap pasiennya. 
Menurut Teori Low Context Culture \& High Context Culture yang dikemukakan oleh Edward T. Hall dalm buku Pengantar Ilmu Komunikasi (Mulyana 2007, 327), Low context culture terdapat pada masayrakat yang menganut budaya individual. sedangkan High context culture terdapat pada masyarakat yang menganut budaya kelompok. Edward T. Hall (1973) menjelaskan perbedaan konteks budaya tinggi dan konteks budaya rendah. Budaya konteks tinggi ditandai dengan komunikasi konteks tinggi, yaitu kebanyakan pesan bersifat implisit tidak langsung dan tidak terus terang. Pesan yang sebenarnya tersembunyi dalam perilaku nonverbal pembicara: intonasi suara, gerakan tangan, postur badan, ekspresi wajah, tatapan mata atau bahkan konteks fisik (dandanan, penataan ruangan, benda-benda dan sebagainya). Pernyataan verbalnya bisa berbeda atau bertentangan dengan pesan nonverbal. Hal inilah yang dilakukan healer/penyembuh pengobatan alternative minyak bintang. Mereka menggunakan High context communication yang dapat memberikan pesan kepada pasien bahwa mereka bisa sembuh secara aman, cepat dan murah. Hal ini tentu berbeda dengan petugas kesehatatan yang biasanya menggunakan pola low context communication kepada pasiennya. Mereka cenderung eksplisit dalam menjelaskan pesan-pesan yang ingin disampaikan kepada pasiennya.

Hasil yang diharapkan dalam penelitian ini adalah dapat digunakan untuk memberikan penjelasan kepada pembaca tentang penggunaan pola komunikasi tingkat tinggi yang digunakan penyembuh minyak bintang dalam penyampaian pesan kepada pasien yang lebih efektif daripada penggunaan pola komunikasi tingkat rendah yang dilakukan petugas kesehatan di kota Samarinda.

\section{METODE PENELITIAN}

Dalam penelitian ini penulis menggunakan metode Etnografi. Etnografi sebagai metode tertua dalam riset kualitatif sangat penting untuk penelitian-penelitian social yang mempunyai beberapa cirri khas yaitu (1) Lebih menekankan upaya eksplorasi terhadap sifat dasar fenomena sosial tertentu, bukan melakukan pengujian hipotesis atau fenomena tersebut, (2) data tidak terstruktur; (3) kasus atau sample sedikit; (4) dilakukan analisis data dan interpretasi data tentang arti dari tindakan manusia (Denzin dan Lincoln 2009, 316)

Etnografi juga merupakan pendekatan kualitative riset popular yang berfokus pada kultur/budaya. Istilah etnografi berasal dari kata ethno (bangsa) dan graphy (menguraikan), jadi etnografi yang dimaksudkan adalah untuk menguraikan kebudayaan atau aspek-aspek kebudayaan (Mulyana 2003, 161). Creswell menegaskan bahwa Etnografi merupakan sebuah penelitian yang berfokus penuh pada sebuah kelompok budaya. Kelompok budaya yang 
menjadi fokus tersebut bisa saja dalam scope yang kecil (sekumpulan individu), atau dalam skala yang lebih besar dan terkait dengan sekumpulan orang atau banyak orang yang saling berinteraksi sepanjang waktu, seperti sebuah komunitas sosial dari kelompok pekerja. Creswell menjelaskan pula bahwa etnografi adalah sebuah desain dari penelitian kualitatif dimana peneliti mencoba menjelaskan dan mengintepretasikan suatu kebudayaan, kelompok sosial atau sistem yang ada di masyarakat. Peneliti yang bisa disebut sebagai Etnograf mencoba menguji suatu kelompok dan mencoba mempelajari pola perilaku, adat istiadat, gaya hidup, yang tercermin dalam keseharian yang ada di kelompok tersebut. Peneliti berusaha menguji dan mempelajari keseharian kelompok tersebut baik sebagai suatu proses maupun hasil dari penelitian.

“..An ethnography is a description and interpretation of a cultural or social group or system. The researcher examines the group "s observable and learned patterns of behavior, customs, and ways of life.." (Harris, 1968 on Creswell 2013, 125).

Bagi Agar (1980) dalam Creswell $(2013,125)$, etnografi adalah sebuah produk dari suatu penelitian, dan outputnya biasanya berbentuk sebuah tulisan yang terrangkum dalam sebuah buku. Namun di sisi lain, etnografi juga dapat dipahami sebagai sebuah proses, dimana sang peneliti melibatkan diri pada sebuah observasi panjang terhadap kelompok tertentu.

Etnografi lazimnya bertujuan untuk menguraikan suatu budaya secara menyeluruh, yakni semua aspek budaya secara menyeluruh, yakni semua aspek budaya, baik material secara artefak dan budaya (alat-alat, pakaian, bangunan dan sebagainya) dan yang bersifat abstrak, seperti pengalaman, kepercayaan, norma dan sistem nilai kelompok yang diteliti. Uraian tebal (think description) merupakan ciri utama etnografi (Mulyana 2003, 161). Etnografi merupakan kegiatan penulis untuk memahami cara orang-orang berinteraksi dan bekerja sama melalui fenomena teramati kehidupan sehari-hari. Etnografi melibatkan pengamatan yang luas terhadap kelompok tersebut, seringkali melalui pengamatan partisipan, yang penelitinya menenggelamkan diri dalam kehidupan sehari-hari dari masyarakat tersebut mengamati dan mewawancarai para partisipan dalam kelompok tersebut (Creswell 2013, 125). Dengan kata lain, penulis terlibat secara langsung dengan objek penulisan dalam melakukan pemaknaan atau interpretasi terhadap penulisan yang dilakukan.

\section{Teknik Pengumpulan Data}

Teknik pengumpulan data dalam etnografi menggunakan observasi partisipasi, data diperoleh melalui partisipasi di dalam kehidupan sehari-hari 
informan dalam kondisi yang sebenarnya dalam rangka mendapatkan interpretasi mereka dan makna sosial dari tindakan dan kegiatan tersebut (Brewer 2000, 59). Hammersley\& Atkinson (1983) dalam Denzin dan Lincoln (2009, 317) menyebutkan bahwa observasi partisipasi tidak hanya menempatkan peneliti sebagai bagian dari subyek penelitian tersebut tetapi juga bagaimana caranya seorang peneliti dapat menghadirkan pandangan dunia subyek penelitian tersebut sebagaiagian dari karakteristik penelitiannya. Instrument terpenting dalam teknik ini adalah peneliti itu sendiri, dimana seorang peneliti harus mampu membangun atau menempatkan diri sebagai orang "dalam"sekaligus sebagai orang "luar" dari masyarakat tersebut. Untuk mencapai tujuan tersebut, maka seorang peneliti etnografi dituntut untuk menguasai bahasa informannya (Brewer, 2000:59).

Data etnografi juga diperoleh dengan melakukan wawancara mendalam (depth interview) dalam bentuk wawancara tidak terstruktur. Wawancara ini menghasilkan respon verbal dari informan. Selain itu data personal dari informan dan riwayat hidupnya menjadi data pendukung dalam melakukan analis a etnografi (Brewer 2000, 73).

Dokumen juga merupakan data yang ikut diperoleh selama penelitian ini. Dokumen merupakan catatan peristiwa yang telah berlalu. Dokumen bisa berbentuk tulisan, gambar, maupun hal-hal lain yang dapat menunjang hasil dari penelitian. Studi dokumen merupakan pelengkap dan penggunaan metode observasi dan wawancara dalam sebuah penelitian kualitatif.

\section{Subjek Penelitian}

Moleong (2006, 132) mendeskripsikan subjek penelitian sebagai informan, yang artinya orang pada latar penelitian yang dimanfaatkan untuk memberikan informasi tentang situasi dan kondisi latar penelitian. Adapun subyek penelitian dalam tulisan ini adalah masyarakat Kota Samarinda yang melakukan pengobatan Alternatife minyak bintang dan penyembuh minyak bintang. Dengan 6 orang informan termasuk pasien dan salah satunya dari kalangan penyembuh/healer minyak bintang.

\section{HASIL DAN ANALISIS PENELITIAN}

Ada dua versi yang menjelaskan apa itu dan dari bahan apa minyak bintang itu dibuat. Versi pertama adalah dari cerita yang beredar di masyarakat samarinda. Minyak bintang berasal dari sebuah kekuatan ghaib seperti dari air liur HANTUEN - sejenis makhluk 
jejadian di Kalimantan, bahkan ada juga cerita yang berkembang bahwa minyak bintang adalah minyak dari air bekas memandikan mayat bayi. Tetapi asal minyak bintang yang berasal dari bahan mayat ular adalah yang paling diakui oleh sebagian pengguna minyak bintang di Samarinda.

Versi kedua adalah informasi langsung dari narasumber yang telah penulis lakukan wawancara. Beliau biasa dipanggil dengan sebutan "Kai Janggut" oleh sebagian pasiennya. Beliau adalah seorang penyembuh/healer yang menggunakan media terapi minyak bintang sebagai bahan utama penyembuhan patah tulang dan luka berat lainnya. Menurut beliau, minyak bintang yang dia peroleh beliau dapatkan dari saudaranya yang memang mempunyai kemampuan membuat minyak bintang sekitar 20 tahun yang lalu. Walaupun saat ini saudara beliau sudah berpulang, tetapi minyak bintang yang telah dibuatnya masih bersisa dan masih mampu menyembuhkan ratusan orang lagi.

Menurut Kai Janggut sebagai orang yang diwariskan ilmu mengobati menggunakan metode minyak bintang dari saudaranya, minyak bintang yang beliau punya berasal dari campuran minyak kelapa, kapas "bujang" dan burung "bubut". Minyak kelapa yang digunkan adalah minyak kelapa biasa. Sedangkan yang dimaksud dengan kapas 'bujang' adalah kapas yang yang baru saja berbuah dan tidak sempat jatuh ke tanah. Khusus untuk burung bubut, Kai Janggut mengatakan bahwa burung 'bubut' adalah burung yang tinggal di pedalaman hutan. Burung 'bubut' tersebut dipatahkan hidup-hidup hingga mati kemudian direbus lama hingga hanya berbentuk minyak. Kemudian semua bahan dicampur menjadi satu.

Cara pembuatan minyak bintang juga tidak sembarangan, harus dibuat oleh orang yang memiliki amalan tertentu dan harus dibuat pada malam jumat ketika bintang bersinar terang. Konon dari situlah nama dari minyak bintang berasal. Orang yang mampu membuat minyak bintang selain karena mempunyai amalan tertentu, haruslah wanita yang tidak memiliki waktu datang bulan lagi. Hal ini mengindikasikan, bahwa minyak bintang ternyata dibuat oleh wanita yang sudah tua dan bukan oleh laki-laki seperti perkiraan banyak orang.

Minyak Bintang dipercaya mampu menyembuhkan berbagai macam penyakit bahkan patah tulang hanya kurang dari seminggu. Biasanya pasien yang datang untuk berobat, diwajibkan membawa mahar untuk pengobatan. Mahar untuk pengobatan berbeda-beda, tergantung yang diminta oleh penyembuh. Khusus Kai Janggut, beliau hanya meminta dibawakan sebuah jarum atau apapun yang berbentuk tajam ukuran kecil seperti peniti atau sebagainya. Kemudian Jarum tersebut dicelupkan ke dalam wadah yang berisi minyak bintang, Minyak yang sudah diberikan mahar tersebut langsung akan diambil sebanyak 2 
sampai 3 tetes yang kemudian akan dimasukan ke dalam kapsul kosong. Setelah itu Kai janggut akan membacakan doa-doa dan wejangan agar tetap tawakhal dan percaya tuhan akan menyembuhkannya. Langkah terakhir hanya tinggal meminta pasien agar meminum minyak bintang tersebut. untuk kasus tertentu, terkadang minyak bintang hanya dioleskan sedikit ke bagian yang sakit.

Menurut narasumber pasien yang penulis wawancarai, setelah meminum minyak bintang efeknya berbeda-beda terhadap setiap pasien. Ada yang seperti kesemutan, disayat-sayat bahkan ada yang mengaku sangat sakit sekali seperti ditusuk-tusuk benda tajam. Walaupun efeknya setelah meminum minyak bintang berbeda-beda, para pasien yang penulis wawancarai semuanya mengakui bahwa proses penyembuhan oleh minyak bintang berlangsung sangat cepat.

Seperti dikutip dalam tulisannya (Mulyana 2008, 10) dari bukunya Mullavey-O’Byrne terdapat tiga paradigma atau sistem untuk menelaah kesehatan, keadaan sakit dan penyakit yaitu sistem biomedis, sistem personalistik, dan sistem naturalistik. Menurut sistem biomedis yang dominan di Barat sejak abad ke-18 hingga kini penyakit merupakan akibat dari abnormalitas fungsi atau struktur tubuh; penyakit disebabkan oleh virus atau bakteri, kecelakaan dan usia tua. Keadaan sakit, seperti juga keadaan sehat, adalah fenomena objektif yang disebabkan oleh faktor-faktor tertentu yang dapat diteliti secara ilmiah di laboratorium. Penyembuhannya melalui pembedahan dan pengobatan kimiawi.

Sesungguhnya pasien yang berobat menggunakan media minyak bintang percaya bahwa penyakit patah tulang dan luka berat yang mereka derita akibat dari abnormalitas fungsi atau struktur tubuh. Tetapi mereka beralih kepada Minyak bintang yang sesungguhnya malah masuk dalam katagori pengobatan personalistik. Penyakit personalistik dikategorikan sebagai penyakit yang disebabkan oleh agen-agen tertentu (Foster dan Anderson, 1986). Minyak bintang masuk dalam katagori pengobatan personalistik.

Di dalam buku Antropologi Kesehatan karangan Foster dan Anderson Personalistik menganggap munculnya penyakit (illness) disebabkan oleh intervensi suatu agen aktif yang dapat berupa makhluk bukan manusia (hantu, roh, leluhur atau roh jahat), atau makhluk manusia (tukang sihir, tukang tenung). Tetapi dalam pengobatan minyak bintang, hal ini sedikit berubah pemahamannya menurut pasien yang menggunakan terapi minyak bintang. Mereka sama sekali tidak merasa bahwa munculnya penyakit akibat intervensi agen yang bukan berupa bakteri ataupun makhluk jejadian lainnya. Akan tetapi mereka tetap percaya ada sesuatu kekuatan tertentu yang di luar rasionalitas mempercepat proses penyembuhan mereka. 
Penyembuh/healer minyak bintang memiliki kemampuan penyajian pesan yang bersifat eksplisit kepada pasiennya. Bila pesan-pesan dimaksudkan untuk mempengaruhi orang lain, maka kita harus menyentuh motif yang menggerakan atau mendorong perilaku komunikate (Jalaludin 2011, 294). Hal inilah yang coba dilakukan oleh penyembuh minyak bintang kepada komunikate (pasien). Untuk itu biasanya penyembuh minyak bintang menggunakan imbauan emosional yang mampu menggerakan hati pasiennya agar merasa bisa dan cepat sembuh. Imbauan emosional menggunakan pernyataan atau bahasa yang menyentuh emosi komunikate (pasien) (Jalaludin 2011, 294). Penyembuh minyak bintang selalu berusaha untuk memahami pasien mereka yang datang berobat, kemudian akan berusaha untuk peduli secara emosional terhadap pasiennya. Hal ini menjadikan setiap pasien yang datang akan merasa dipahami, belum lagi terkadang penyembuh menyisipkan ajaranajaran yang mengingatkan bahwa setiap penyakit akan ada obatnya asal percaya kepada tuhan yang maha esa.

Imbauan pesan seperti ini sangat mungkin terjadi dikarenakan komunikasi konteks tinggi yang coba dipraktekan penyembuh terapi minyak bintang kepada setiap pasien yang datang untuk kesembuhan mereka. Pasien yang datang untuk berobat, mengaku senang dan merasa bahwa penyembuh memang mampu menyembuhkan secara cepat (ghaib) karena mereka memiliki amalan yang baik, tercermin dalam gaya mereka berbicara dan memahami pasien.

Ketika pasien yang datang berobat mencoba untuk sembuh, mereka tidak langsung dijejali oleh keharusan membayar ataupun melakukan syarat-syarat tertetnu agar proses penyembuhan berlangsung lancar. Pertama-tama pasien yang datang akan diberikan nasehatnasehat yang menenangkan jiwa agar tawakal terhadap musibah yang sedang dihadapinya. Ketika pasien sudah tersadar untuk sudah sampai tahap "menerima" segala cobaan. Barulah kemudian penyembuh minyak bintang akan mulai serius dalam mencoba membantu pasien untuk mengobati penyakitnya. Bila emosi mereka sudah disentuh, maka biasanya syaratsyarat yang tidak rasional yang diminta oleh Penyembuh akan dilaksanakan oleh pasien dengan sungguh-sungguh. Seperti diminta membawa mahar, tidak makan ikan asin, menggunakan pisang sebagai media meminum minyak bintang dan sebagainya.

Tentunya Hal ini sangat berbeda apabila, mereka berobat ke rumah sakit. Dokter, perawat ataupun Petugas kesehatan lainnya tentunya akan menyampaikan pesan secara implisit. Bahkan terkadang belum sembuh saja, sudah diinformasikan total estimasi biaya dan lamanya proses penyembuhan. Penggunaan komunikasi konteks rendah di kalangan profesional kesehatan ini sebenarnya sudah sesuai dengan UU No 29 tahun 2004 tentang 
praktik kedokteran pasal 50 dan 51. Yang intinya mewajibkan dokter untuk memberikan informasi secara lengkap tentang tindakan medis yang harus dilakukan kepada pasien. Melihat hal tersebut, seharusnya sudah menjadi hal yang wajar atau bahkan keharusan untuk seorang dokter menyampaikan pesan-pesan yang jelas kepada pasiennya.

Tetapi sebagian masyarakat Indonesia dan sebagian masyarakat Samarinda khususnya adalah penganut budaya konteks tinggi. Mereka tentu, tidak bisa menerima gaya bahasa bersifat langsung dan berterus terang (eksplisit) yang coba dipraktekan petugas kesehatan dalam komunikasi konteks rendah. Mereka ingin merasakan kenyamanan berinteraksi yang awalnya tidak mereka rasakan ketika berobat ke Rumash sakit, sesuai dengan cirri-ciri komunikasi intrapribadi Devito (Liliweri 1991, 13) yaitu Keterbukaan, Empati, Dukungan, Rasa positif dan Kesamaan dalam berinteraksi. Pasien yang enggan berobat menggunakan pengobatan biomedis umumnya bukan karena tidak percaya dengan kemampuan dokter, tetapi karena mereka lebih mendapatkan keterbukaan, empati dan dukungan yang lebih untuk sembuh dari penyembuh minyak bintang dibandingkan oleh petugas kesehatan. Hal ini tercermin dari pendekatan yang dilakukan oleh penyembuh minyak bintang yang lebih banyak memberikan nasehat dan doa kepada pasien. Hal ini tentunya akan dianggap oleh pasien sebagai bentuk empati dan dukungan yang lebih dari penyembuh minyak bintang.

\section{KESIMPULAN}

Tidak ada sebuah pengobatan yang bisa menyembuhkan suatu penyakit yang parah apalagi patah tulang dengan hanya waktu seminggu. Untuk itu sesungguhnya pengobatan Biomedis masih menjadi hal yang dipercayai oleh masyarakat Pengguna minyak Bintang. Tetapi mereka rela berpindah ke pengobatan alternative minyak bintang dikarenakan faktor komunikasi konteks tinggi yang dipraktekan oleh penyembuh/healer minyak bintang. Pasien yang berobat lebih senang pesan yang bersifat eksplisit yang mampu menghadirkan empati terhadap pasien. Hal ini tentunya berbeda dengan petugas kesehatan yang menggunakan komunikasi tingkat rendah yang besifat lugas dan langsung pada intinya (implisit). Untuk itu dibutuhkan kemampuan memahami komunikasi konteks tinggi bagi seluruh petugas kesehatan agar dapat menghadirkan peendekatan budaya dalam menghadapi persoalan yang dihadapi pasien.

\section{DAFTAR PUSTAKA}

Brewer, Johnd. 2000. Ethnography. Philadelphia: Open UniversityPress 
Creswell, John. 2014. Penelitian Kualitatif dan Desain Riset. (Edisi ke 3). Yogyakarta : Pustaka Pelajar.

Denzin, N.K. dan Y.S. Lincoln, 2009. Hanbook of Qualitatif Research. London: Sage Publication.

Foster, George M. \& Anderson 1986. Antropologi Kesehatan. UI Press, Jakarta. Lexy J, Moleong. 2006. Metodologi Penelitian Kualitatif. Bandung: Rosdakarya Mulyana, Dedy. 2007. Pengantar Ilmu Komunikasi, Bandung: Rosdakarya 2008. Metodologi Penelitian Kualitataif, Bandung : Rosdakarya

Rakhmat, Jalaludin. 2011. Psikologi Komunikasi, Bandung: Rosdakarya.

Samovar, L. A., Porter, R. E., \& McDaniel, E. R. (2010). Communication Between Cultures (7th Edition ed.). Boston, USA: Wadsworth Cengage Learning.

\section{BIOGRAFI PENULIS}

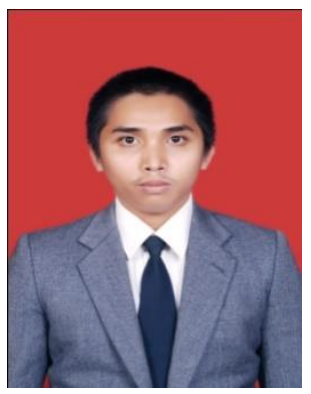

Mochammad Wahyu Ghani dilahirkan pada tanggal 2 Maret 1992 di Temangung, Jawa Tengah. Menyelesaikan pendidikan S-1 di Universitas Padjajadran, Program studi Ilmu Informasi dan Perpustakaan dengan skripsi berjudul Proses Penyebaran Informasi Melalui Program SHEQ talks (2014). Pernah menjabat sebagai ketua Himpanan Mahasiswa Ilmu Informasi dan Perpustakaan (2011-2012) dan juga anggota senat Fakultas ilmu komunikasi universitas padjadran (2012). Di organisasi tingkat nasional pernah menjabat menjadi Sekjen DPD I HMPII (Himpunan Mahasiswa Perpustakaan dan Informasi Indonesia) Saat ini, Ia sedang menjalani semester ke-3 nya di Pascasarjana Fakultas Ilmu Komunikasi Universitas Padjadjaran, program studi Komunikasi konsentrasi Komunikasi Kesehatan. 